\title{
Complex vertebral malformation syndrome in Holstein cattle: the story so far Jørgen S Agerholm
}

\begin{abstract}
Address: Department of Veterinary Pathobiology, Faculty of Life Sciences, University of Copenhagen, Ridebanevej 3, DK-1870 Frederiksberg C, Denmark

Email: Jørgen S Agerholm - jager@life.ku.dk
\end{abstract}

from Perinatal Death In Domestic Animals: The 20th Symposium of the Nordic Committee for Veterinary Scientific Cooperation (NKVet) Reykjavik, Iceland. 26-27 April 2007

Published: 12 December 2007

Acta Veterinaria Scandinavica 2007, 49(Suppl I):S5 doi:10.1186/175I-0147-49-SI-S5

This abstract is available from: http://www.actavetscand.com/content/49/SI/S5

(c) 2007 Agerholm; licensee BioMed Central Ltd.

The complex vertebral malformation syndrome (CVM) is a congenital autosomal recessively inherited disorder in Holstein cattle [1]. The syndrome is associated with extensive foetal mortality as analyses of population-based breeding results have demonstrated a significant lack of calves born near term. Studies of Danish Holsteins have shown that the extent of foetal mortality prior to gestation day 260 is approximately $77 \%$ [2].

Calves that survive to the end of the gestation period are mostly stillborn and morphologically characterized by growth retardation and mild bilateral flexion of the carpal and pastern joints with rotation of the digits. Additionally, most animals have vertebral malformation, malformed ribs, and arthrogryposis of the tarsal and posterior pastern joints. Extensive malformation of cervical and thoracic vertebrae is found in typical cases causing shortening of the neck, but the extent of vertebral malformation varies considerably between cases. Other malformations have been reported as a part of this syndrome, including cardiac interventricular septal defects, malformation of the great vessels and myocardial hypertrophy [1].

Genomic analysis has identified a single base substitution in the gene SLC35A3 as the cause of CVM. The gene SLC35A3 codes for a nucleotide-sugar transporter in which the base mutation is reflected in a critical amino acid substitution, thus inhibiting the function of the transporter. The nucleotide-sugar transporter plays an essential role in mechanisms controlling the formation of vertebrae from the unsegmented paraxial mesoderm. Consequently, the defective transporter molecule leads to vertebral malformations [3]. The genomic analysis has formed the basis for the development of commercially available genotyping tests.

Retrospective studies have traced the origin of the defective allele to the US Holstein sire Penstate Ivanhoe Star (US1441440, born in 1963). One of his sons Carlin-M Ivanhoe Bell (US1667366), which received the defective allele from his father, founded an important and worldwide distributed breeding line. Consequently, carriers of CVM have been identified among sires used for artificial insemination (AI) worldwide at high prevalence, i.e. around 30\% [3]. More than 500 sires used for AI in Denmark have been identified as carriers of CVM, but extensive genotyping of potential breeding sires and culling of carriers have reduced the prevalence to around zero. Prior to breeding measures taken to limit the prevalence of $\mathrm{CVM}$, this syndrome was probably the most frequent inherited disorder in Holsteins ever recorded.

CVM has had major impact on the on the reproductive performance in Holsteins. Berglund and co-workers [4] estimated that 2,200 affected foetuses were produced annually between 1995 and 1999 in Sweden, while the annual loss in Germany was estimated to be more than 8,000 foetuses between 1997 and 2000 [5]. In Denmark, estimates have shown that around 12,000 cases have occurred until December 31, 2005. The economic impact of reproductive problems of this magnitude is considera- 
ble. British researchers [6] have estimated that the total costs, including lost milk production and premature culling, associated with a case of CVM is $£ 419$ (2005 level). Based on these estimations the economic loss in Denmark can be calculated to around $£ 5$ million or DKK 50 million.

\section{References}

I. Agerholm JS, Bendixen C, Andersen O, Arnbjerg J: Complex vertebral malformation in Holstein calves. J Ve Diagn Invest 200I, 13:283-289.

2. Nielsen US, Aamand GP, Andersen O, Bendixen C, Nielsen VH, Agerholm JS: Effects of complex vertebral malformation on fertility traits in Holstein cattle. Livestock Prod Sci 2003, 79:233-238.

3. Thomsen B, Horn P, Panitz F, Bendixen E, Petersen AH, Holm LE, Nielsen VH, Agerholm JS, Arnbjerg J, Bendixen C: A missense mutation in the bovine SLC35A3 gene, encoding a UDP-Nacetylglucosamine transporter, causes complex vertebral malformation. Genome Res 2006, 16:97-105.

4. Berglund B, Persson A, Stålhammer H: Effects of complex vertebral malformation on fertility in Swedish Holstein cattle. Acta Vet Scand 2004, 45:161-165.

5. Konersmann Y, Wemheuer W, Brenig B: Herkunft, Verbreitung und Bedeutung des CVM-Gendefekts in der Holstein-Friesian-Population. Züchtungskd 2003, 75:9-15.

6. Kearney JF, Amer PR, Villanueva B: Cumulative discounted expressions of sire genotypes for the complex vertebral malformation and $\beta$-casein loci in commercial dairy herds. J Dairy Sci 2005, 88:4426-4433.

Publish with Bio Med Central and every scientist can read your work free of charge

"BioMed Central will be the most significant development for disseminating the results of biomedical research in our lifetime. "

Sir Paul Nurse, Cancer Research UK

Your research papers will be:

- available free of charge to the entire biomedical community

- peer reviewed and published immediately upon acceptance

- cited in PubMed and archived on PubMed Central

- yours - you keep the copyright

Submit your manuscript here:

http://www.biomedcentral.com/info/publishing_adv.asp 